\title{
INTANGIBLE RESOURCE MANAGEMENT - AN ORGANISATIONAL APPROACH
}

\author{
Sebastian Emanuel STAN \\ "Lucian Blaga" University of Sibiu, Romania \\ officesstan@gmail.com
}

\begin{abstract}
This article is seeking to improve the intangible resource management at organisation level by highlighting the importance of this type of management on one hand and, on the other hand, by creating a pattern describing the process to be followed by the organisations that wish to implement an intangible resource management system. Thus, this study shows the premises underlying the author's approaches on the importance of intangible resource management, the concept of intangible resource management is substantiated, and some general principles are formulated regarding the substantiation and implementation of this type of management. Specific processes representing the scope of the management at the organization level are analysed, which may be grouped in five phases largely corresponding to the functions of the intangible resource management. Eventually, the phases for implementing an intangible resource management system are identified.
\end{abstract}

Keywords: resources, intangibles, management

\section{Introduction}

The ability of organisations to exploit their intangible resources is crucial in the current context, especially since the exploitation of physical resources is placed on a second plan. It is therefore necessary to effectively manage intangible resources since a sustained competitive advantage (in Porter's view (1985) a competitive advantage is created when a product can be offered having a sufficiently high value at a cost lower than other competitors could offer on the market) depends on the organisation's ability to create, develop and effectively use these resources [1]. As a result, intangible resources management is a major area not only in the theory but also in the practice of the organisations. However, reality shows that organisations face unexpected challenges in developing and implementing intangible resource management strategies and processes. The most pressing challenges are:
- identifying available intangible resources but also the ones needed to reach the goals;

- developing resource (as permanent "flow" resulting in the enrichment and superior valorisation of the intangible resource "stock") in order to maintain or increase their capacity to generate a sustainable competitive advantage;

- the difficulty to measure and assess intangible resources;

- identifying their impact on organisational performance [2].

The premises underlying our research and approaches on the major importance of managing intangible resources are the following:

- the new knowledge-based epistemic economy - a concept adopted after [3], deeply influences the content and manifestation of the management process in all its components; 
- the need to place intangible resources in the centreplane of the management, since they are regarded, at the same time, as an essential resource, an important asset, a main product and a competitive advantage for organisations, requiring therefore a new type of management [4];

- considering intangible resources as the object of management, as a whole, starting from their origin, sources of training, types, sizes, traits, and also on their specific features, and pursued on several plans.

The management of intangible resource, for the purpose of this paper, refers to the processes and practices used by the organisations to increase their value, by developing the efficiency of creating and exploiting the intangible resources they have.

Intangible resource management is a much wider concept than knowledge management [5]. Its main purpose is to increase the value of the firm by creating competitive advantages. The management of intangible resources involves identifying these resources, assessing their impact on the present and future value of the firm, assessing them, discovering intangible activities, and ultimately their ability to effectively manage these activities. Creating knowledge is an intangible resource that organisations need to manage just as they manage other resources of this nature; therefore knowledge management is a subset of intangible resource management.

Based on our own analysis and taking into account different approaches found in the literature, we have formulated some general principles related to creating and implementing the intangible resources management, which refers to:

- focusing the management on efficient and complex management of intangible resources within the organisation, taking into account that the management of intangible resources requires managers and managerial bodies specialised in this respect;

- intangible resources management is a process which continues incessantly, as long as the organisation exists and operates;

- protecting intangible resources within the organisation, due to their location at the foreground of organisation management;

- intangible resources are important power sources at the level of individuals and organisations, these being a key element of the organisation's functionality and performance;

- treating intangible resources in a right and proper way, by highlighting their dependence on human capital;

- addressing and using intangible resources in their multi-variety and multi-dimensionality, focusing on those of strategic importance to the organisation;

- the firm must move towards a lifelong learning organisation, by using both individual learning and organisational learning so as to be able to gather as much information and knowledge as possible and use it in the most effective way;

- the assessment of the need to implement both an intangible resource management, and also its quality and its decision-makers will be based on the performance obtained.

It is certain that the management of intangible resources involves quite high costs. It is an expensive management, especially if we take into account the logistics required, the specialists used and the processes of creating, developing, use, protection, etc. of these resources that must be carried out on an ongoing basis. Despite these issues, non-implementation of this type of management will generate even higher costs, causing major organisational problems in the future that may lead to bankruptcy. Thus, organisations benefiting of effective management react quickly and 
adjust to this reality by adopting strategies that they apply consistently by developing decision-making, organisational, informational and motivational mechanisms to generate positive results/ efforts, and income / costs respectively.

\section{Specific processes of intangible resource management}

In a technical approach, intangible resources management is a set of activities in which the fundamental functions of management are applied to a set of specific processes related to intangible resources, understood as organisational resources of strategic importance. These processes can be used to increase and maintain the intellectual capital, or the intangible resources of an organisation.

Specific processes which are part of the organisation management object are numerous, but they can be divided into five phases roughly corresponding to the functions of intangible resources and management and they refer to (see Figure 1):

1. Forecasting the needs and sources of intangible resources. This process is done starting, of course, from what there exists and from the mission and strategic objectives of the firm. It is important that any managerial context related to intangible resources should be linked to the overall managerial context of the organisation. The quality and performance of the intangible resource management system does not guarantee an organisation gaining the competitive advantage if its overall strategy is not properly targeted and dimensioned [6].

2. Generating intangible resources (by purchase and creation). Particular attention is paid to determining the main ways in which the organisation obtains intangible resources. Getting them from the inside and outside of the organisation also includes generating new intangible resources when the existing ones are not enough and they cannot be obtained from the outside, since they cost too much or it is preferable to create them within the organisation itself, due to the strategic function they have.

3. The management, use and development of intangible resources. This phase is often formed by the majority of the processes treating these resources in an organisation. Within this framework, a complex of operations is being carried out on these resources, mostly of a repetitive character, generating highly important products and services, with innovative character. The laborious character of these processes, with many technical, human and economic facets, is to be taken into consideration. Among these, we can mention: identification and mapping: after identifying intangible resources, the means and methods are defined through which they can be accessed; sharing: the process that allows the dissemination of knowledge on intangible resources within the organisation; the use/ application of intangible resources and knowledge to a certain, well determined purpose, in order to solve a given problem.

4. The use of intangible resources gives purpose to the previous phases, being the stage where the company collects the economic benefits of the intense previous work processes. As a rule, this phase takes place on the market through marketing, but as a specific aspect, following the integration of the company into various networks. The use of intangible resources may be done with partners even within the organisation.

5. Besides these specific functions and phases, the management must also exercise a quasi-permanent function, accompanying the preceding ones protecting intangible resources of the organisation [7]. Undertaking it is particularly difficult since most of these resources are not tangible, some of them 
are individual, belonging to employees or other stakeholders. Effective protection of intangible resources incorporates processes and activities related to employee training, to building of an individual pro-development climate and pro-innovation within the
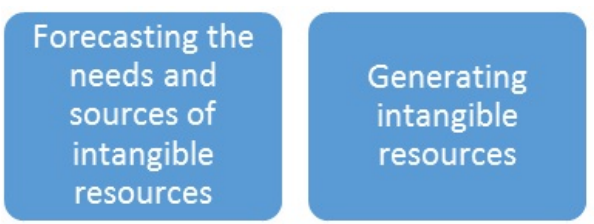

organisation, encouraging employees, taking actions to increase stakeholders' participation in the actions of the organisation, attracting potentially competing organisations into production and marketing networks etc. [8].

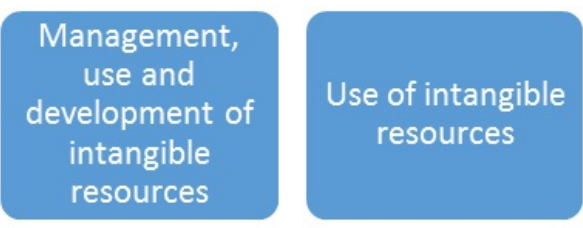

\section{Protect the organisation's intangible resources}

Figure 1: Specific processes forming the object of organisation management

\section{Phases of implementing an intangible resource management system}

In the following lines, we briefly describe the steps to be taken by an organisation that is aware of the importance of intangible resources for the success of its work and is willing to adjust its management control system to explicitly take into account intangible resources. Organisations also need to treat intangible resources management as a strategic issue closely related to the capacity of these resources to create value, and intellectual capital as an essential part of their business processes.

When implementing an intangible resource management system, we consider necessary the following three successive phases according to the pattern developed by Sanchez et. al (2000) (figure 2):
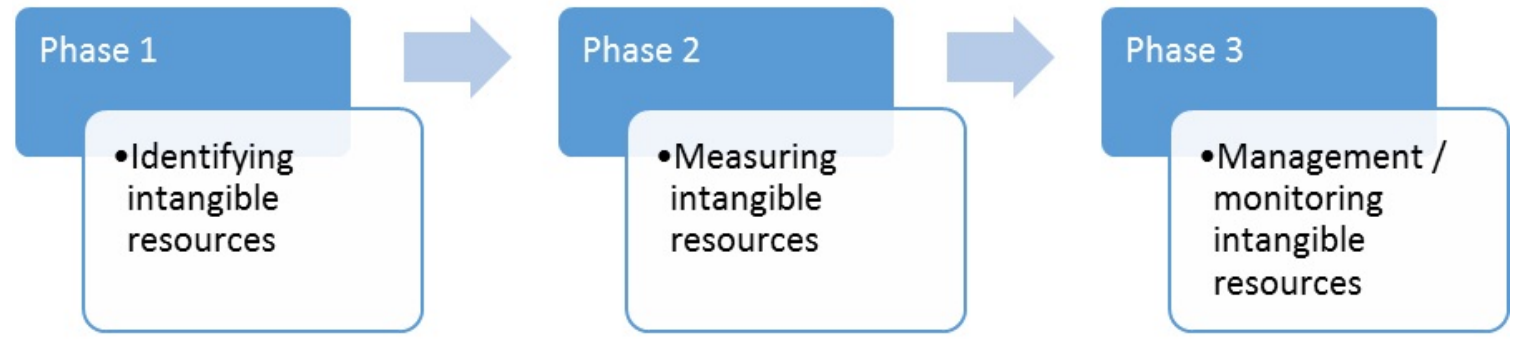

Figure 2: Intangible resource analysis model [9]

The identification phase focuses on the socalled critical intangible resources. The organisation must determine what its strategic objectives are and which of the intangible resources are most closely related to them. Then, they need to identify what they need to do in order to create and increase these critical intangible resources, more specifically, the activities positively and negatively affecting intangible resources (dynamic dimension). It is important not to focus only on those activities that could increase the level of critical intangible resources, but also to consider those that may hinder or decrease the level of these resources. In the next step, it is necessary to identify the measures to monitor the level of these intangible resources and the performance of selected intangible activities.

The pattern should be understood in a dynamic sense. The organisation measures the level of intangible resources at a given time ( $\mathrm{t})$. Then various activities are 
developed that could affect these resources, measuring them again during $(t+1)$ period. In this way, the firm may monitor any changes in intangible resources as a result of management procedures.

\section{Conclusions}

All organisations have an interest in maintaining and enhancing their intellectual capital assets, and the management of intangible resources is a helpful way of achieving this goal. Generating and enhancing intellectual capital is practically an organisational goal, whilst intangible resources management is the means by which this goal is achieved, being a process taking place within the organisation. Intangible resource management is a concept much wider than knowledge management. Its main purpose is to increase the value of the firm by creating competitive advantages. The management of intangible resources involves identifying these resources, assessing their impact on the present and future value of the firm, their assessment, the discovery of intangible activities, and ultimately the ability to effectively manage these activities. Creating knowledge is an intangible resource that organisations need to manage just as they manage other resources of this nature, so knowledge management is a subset of intangible resource management.

Despite its importance, organisations are faced with a number of difficulties in implementing intangible resource management, especially in identifying, assessing and monitoring intangible resources.

In conclusion, under the new knowledgebased economy, organisations need to adjust themselves in order to gain a dominant position, in order to survive and develop. Intangible resource management may be regarded as a core branch of organisational management during this period. That is why the trend of economic research in the coming years will probably go towards finding realistic methods of calculating the value brought by the intellectual capital in knowledge-based organisations.

\section{References}

[1] Perez J. R., Pablos P. O., Knowledge management and organizational competitiveness: A framework for human capital analysis. Journal of Knowledge Management, 7(3), pp. 82-91, 2003.

[2] Hsieh H.-J., Organizational characteristics, knowledge management strategy, enablers and process capability: knowledge management performance in U.S. software companies, UMI Number: 3256804, ProQuest, 2007.

[3] Apetroae M., Capitalul intelectual și economiile epistemice, Ed. Focus Opinfo, București, 2004.

[4] Oprean C., Țîțu M., Managementul calității în economia și organizația bazate pe cunoștințe, Ed. AGIR, București, pp. 43, 2008.

[5] Sanchez M. P., Chaminade C., Olea M., Management of intangibles: an attempt to build a theory, Journal of Intellectual Capital, 1(4), pp. 312-327, 2000.

[6] Apetroae M., Capitalul intelectual și economiile epistemice, Ed. Focus Opinfo, București, pp. 131, 2004.

[7] Oprean C., Țîțu M., Bucur V., Managementul global al organizației bazată pe cunoștințe, Ed. AGIR, București, pp. 67, 2011.

[8] Oprean C., Țîțu M., Managementul calității în economia și organizația bazate pe cunoștințe, Ed. AGIR, București, pp. 48, 2008.

[9] Sanchez M. P., Chaminade C., Olea M., Management of intangibles: an attempt to build a theory, Journal of Intellectual Capital, 1(4), pp. 312-327, 2000. 